\title{
Intizar
}

Vol. 25, No. 1, Juni 2019

Website: http://jurnal.radenfatah.ac.id/index.php/intizar

ISSN 1412-1697, e-ISSN 2477-3816

\section{Revitalisasi Masjid dalam Membangun Karakter pada Komunitas Melayu Sambas}

\author{
Masmuri $^{1}$, Bayu Suratman ${ }^{2 *}$ \\ ${ }^{1}$ STIKES YARSI Pontianak, Indonesia, m4smuri1984@gmail.com \\ ${ }^{2 *}$ UIN Sunan Kalijaga Yogyakarta, Indonesia, bayusuratman2003@gmail.com
}

DOI: https://doi.org/10.19109/intizar.v25i1.3238

\begin{abstract}
Abstrak
Penelitian ini bertujuan untuk mengetahui revitalisasi masjid dalam membangun karakter pada komunitas Melayu Sambas. Masjid bukan hanya berfungsi sebagai tempat ritual keagamaan tetapi pada fungsi lain yaitu bidang sosial, ekonomi, budaya, dan pendidikan. Metode penelitian yang digunakan adalah penelitian kualitatif, didekati secara sosiologis dan ditulis secara deskriptif berdasarkan wawancara dan pengamatan mendalam terhadap objek yang diteliti. Penelitian ini menunjukkan bahwa sebuah tren positif tentang posisi masjid yang punya peran dalam membangun karakter. Kegiatan-kegiatan masjid pada komunitas Melayu Sambas berpengaruh dalam membangun karakter yang ditandai oleh jumlah jemaah salat bertambah; digelarnya diskusi, ceramah, dialog keagamaan; tempat pembinaan remaja dan anak usia dini; dan tempat musyawarah.
\end{abstract}

Kata Kunci: Revitalisasi, Masjid, Character Building

\begin{abstract}
This study aims to determine the revitalization of the mosque in building character in the Sambas Malay community. The mosque does not only function as a place of religious ritual but in other functions, namely the social, economic, cultural, and educational fields. The research method used was qualitative research, approached sociologically and written descriptively based on interviews and in-depth observations of the objects studied. This research shows that a positive trend about the position of the mosque has a role in building character. Mosque activities in the Sambas Malay community have an effect on building character characterized by an increasing number of congregational prayers; holding discussions, lectures, religious dialogues; a place for youth and early childhood development; and deliberations.
\end{abstract}

Keywords: Revitalization, Mosque, Character Building

\section{Pendahuluan}

Suku Melayu Sambas tidak bisa dipisahkan dari agama Islam yang dianutnya, sehingga dalam kesehariannya sulit memisahkan komunitas Melayu Sambas dari simbol dan nilai ajaran Islam. Sehingga saat mendengar istilah Sambas, yang dimaksud adalah sebuah komunitas Melayu yang dalam kehidupanya sehari-hari dilingkari oleh simbol dan nilai-nilai Islam. Erwin Mahrus dan Moh. Haitami Salim (2008) menjelaskan terma Islam sebagai sebuah istilah yang tidak selalu harus menunjuk pada suatu agama, meskipun terma ini juga tidak salah, tetapi lebih menunjukan pada misinya, yaitu membawa keselamatan, kedamaian, dan seterusnya. Syarifuddin Jurdi (2014) mengungkapkan Islam sebagai wahyu yang mengajarkan kepada para penganutnya untuk menyebarkan agama ini dengan cara-cara yang penuh hikmah dan bijaksana agar dengan cara itu, orang bisa menerima nilai-nilai Islam yang humanis dan atau nilai-nilai Islam bagi kemaslahatan manusia dan alam, kendatipun mereka yang mengamalkan nilai-nilai humanis Islam tersebut tidak beriman kepada Allah (non muslim), Tuhan yang disembah umat Islam.

Budaya atau kearifan lokal yang tercitra oleh komunitas Melayu Sambas sangat dekat dengan ajaran Islam, serta merembes dalam kesehariannya, pada saat ini menunjukkan pengaruh Islam pada sebuah konstruksi budaya atau kearifan lokal sebagai wujud dari identitas Melayu Sambas. Dalam falsafah 
mereka, "adat bersendikan syariat, syariat bersendikan Kitabullah dan Sunnah Rasulullah." Seperti masjid, yang menjadi objek penulisan ini, bukan saja menjadi pusat ibadah tetapi sebagai pusat budaya atau pewarisan budaya. Sebagaimana disebut Sidi Gazalba, masjid sebagai pusat ibadah dan kebudayaan Islam (Gazalba, 1974).

Bahkan, masjid pertama yang ada di Kalimantan Barat dibangun di Sambas pada masa kerajaan Sambas. Masjid Jami' Keraton Sambas awalnya rumah sultan dan dijadikan musala. Dibangun oleh Sultan Umar Aqomuddin yang memerintah Negeri Sambas pada tahun 1702-1727 M. Kemudian direnovasi oleh putranya Sultan Muhammad Saifuddin dan dikembangkan menjadi masjid Jami, dan diresmikan pada tanggal 10 Oktober 1885 M (Zein, 1999). Merujuk pendapat tersebut maka jelaslah pada komunitas suku Melayu Sambas sangat menjunjung tinggi nilai-nilai Islam dan mempunyai akar historis terhadap penyebaran Islam di Kalimantan Barat.

Sebagai tempat peribadatan dan pusat kebudayaan umat Islam, masjid dan fungsinya mengalami pergeseran. Meskipun begitu, semua analis menyetujui bahwa keberadaan masjid mempunyai arti penting bagi perkembangan sebuah komunitas muslim. Jika dilihat dari sejarah umat Islam pada masa awal, masjid oleh Rasulullah Saw memang diposisikan tidak hanya terbatas sebagai tempat peribadatan saja, melainkan kegiatan sosial, budaya dan kemasyarakatan kerap dilakukan di masjid (Gazalba, 1974).

Sementara saat ini, di mana perubahan sosial berlangsung sangat drastis akibat globalisasi, justru masjid - terutama di daerah urban atau sub urban banyak mengalami reduksi. Sebagian masyarakat secara pragmatis mengkerdilkan makna masjid sebatas tempat peribadatan saja seperti salat, mengaji dan seremonial-seremonial (peringatan hari besar Islam). Dalam perumpamaan Supardi dan Teuku Amiruddin (2001), masjid bagi sebagian komunitas muslim, bagaikan air dan ikan. Padahal masjid yang didefinisikan sebagai "bangunan yang didirikan oleh orang-orang yang beriman, tempat mereka melaksanakan ibadahnya semata-mata untuk mencari rida Allah", mestinya maknanya luas dalam pengertian ibadah yang luas pula. Hal ini diamini oleh Syamsul Kurniawan (2014) yang meneliti tentang posisi masjid melalui pendekatan sejarah, yang menurutnya mulai menyempit dalam artian tidak lagi sebagaimana fungsi masjid pada masa Rasulullah Saw yang menjadi sentra seluruh kegiatan umat Islam, melainkan sebatas tempat salat saja.

Namun hasil riset yang peneliti lakukan, malah tidak menunjukkan adanya keadaan seperti yang digambarkan oleh Supardi dan Teuku Amiruddin atau Syamsul Kurniawan, sebagaimana fenomena komunitas muslim perkotaan. Berdasarkan temuan peneliti di Sambas, sebuah Kabupaten yang ada di Kalimantan Barat, komunitas Melayu Sambas yang masih sangat tradisional justru memosisikan masjid bukan hanya sebatas sarana untuk ibadah atau seremonial saja melainkan juga masih mempertahankan masjid sebagai sentra beberapa kegiatan sosial, budaya, dan kemasyarakatan.

Sejauh ini telah ada sejumlah hasil penelitian berkaitan dengan masjid dan komunitas suku Melayu, seperti penelitian Ismail Ruslan (2012) dengan judul "Pemberdayaan Ekonomi Masyarakat Berbasis Masjid di Pontianak". Selain itu juga ada Lamazi (2015), dalam risetnya yang berjudul "Kosmologi Melayu: Studi Pada Arsitektur Masjid Kesultanan Sambas".

Kedua penelitian di atas hanya fokus pada masjid yang ada di Pontianak dalam pemberdayaan ekonomi masyarakat dan satunya membahas simbol dalam masjid Jami yang ada di Kesultanan Sambas dan tidak terfokus pada revitalisasi fungsi masjid pada masyarakat Melayu Sambas, terutama dalam membangun karakter. Kecuali dua penelitian di atas, juga ada Syamsul Kurniawan (2014), yang meneliti tentang terjadinya pergeseran makna dan fungsi masjid dulu dan sekarang. Dengan demikian, tulisan ini berangkat dari mengisi kekosongan diskursif, sebagaimana tidak dibahas dalam tiga artikel di atas.

\section{Metode Penelitian}

Meode penelitian yang digunakan adalah penelitian kualitatif. Pendekatan penelitian yang dilakukan secara sosiologis dan ditulis secara deskriptif berdasarkan wawancara dan pengamatan mendalam terhadap objek yang diteliti. Sumber data penelitian ini adalah informasi yang peneliti peroleh

Intizar, Vol. 25, No. 1, Juni 2019 
dari informan-informan di lapangan penelitian, yang relevan untuk menjawab fokus penelitian. Penelitian ini dilakukan di kecamatan Semparuk Kabupaten Sambas Provinsi Kalimantan Barat.

\section{Hasil Penelitian dan Pembahasan}

\section{Komunitas Melayu Sambas di Semparuk}

Semparuk, lokasi di mana penelitian ini dilakukan, merupakan salah satu kecamatan yang ada di kabupaten Sambas dan merupakan kecamatan keempat di kabupaten Sambas yang dibentuk sejak berlakunya Undang-Undang Nomor 22 Tahun 1999 tentang Pemerintahan Daerah. Semparuk dahulunya merupakan bagian dari kecamatan Pemangkat dan kecamatan Semparuk secara resmi terbentuk pada hari Selasa tanggal 3 Juni 2003. Secara geografis kecamatan Semparuk sebelah Utara berbatasan dengan Sungai Sambas Besar; sebelah Selatan berbatasan dengan Kecamatan Selakau; sebelah Timur berbatasan dengan kecamatan Tebas; sebelah Barat berbatasan dengan kecamatan Pemangkat. Sedangkan secara administrasi kecamatan Semparuk terdiri dari 5 desa, yaitu: desa Seburing, Semparuk, Singaraya, Sepinggan dan Sepadu (Wikipedia, 2019). Penduduk di kecamatan Semparuk pada tahun 2016 sebanyak 25.241 jiwa dengan jumlah laki-laki sebanyak 12.306 jiwa dan perempuan sebanyak 12.935 jiwa (Sambas, 2017).

Secara umum penduduk Kecamatan Semparuk mayoritas suku Melayu dan beragama Islam. Hal ini sesuai dengan pendapat Hermansyah (2015) menyebut Melayu sebagai penganut ajaran Islam. Selain itu, Islam sebagai penanda identitas kemelayuan seseorang. Bahkan, tidak sedikit yang beranggapan apabila ketika seseorang masuk Islam maka akan disebut masuk Melayu. Banyaknya umat Islam yang ada di Kecamatan Semparuk sebanding dengan jumlah berdirinya rumah ibadah umat Islam, yaitu masjid. Masjid di kecamatan Semparuk saat ini sebanyak 33 unit dengan rincian sebanyak 7 masjid di desa Seburing; sebanyak 5 masjid di di desa Sepadu; sebanyak 7 masjid di desa Sepinggan; 4 masjid di desa Semparuk; dan sebanyak 10 masjid di desa Singaraya (Kemenag, 2018).

Banyaknya masjid di kecamatan Semparuk membuat aktivitas keagamaan berjalan dengan baik yang dilakukan oleh masyarakat Melayu Sambas di Intizar, Vol. 25, No. 1, Juni 2019 kecamatan Semparuk. Kegiatan-kegiatan Peringatan Hari Besar Islam (PHBI) selalu dilaksanakan di masjid serta acara-acara resmi lainnya seperti Musabaqah Tilawatil Qur'an (MTQ) kecamatan Semparuk yang dilakukan setiap tahun dan bertepatan dengan bulan Ramadan. Peran masjid sangat berpengaruh terhadap keakraban masyarakat Melayu Sambas di Sepadu terlebih bagi remajaremaja yang ada di setiap desa sebagaimana disampaikan Bapak Amat dan Aunur Rafiq.

Setiap hari besar Islam para aktivis masjid saling mengundang untuk datang dalam acara yang dilaksanakan di masjid. Terlebih pada saat bulan suci Ramadan setiap remaja masjid yang ada di setiap masjid saling bersilaturahmi dengan buka puasa bersama dan dilanjutkan salat Tarawih. Selain itu, bagi remaja masjid yang sebagai tamu biasanya memberikan tausiah atau kultum pada saat selesai salat Isya sebelum salat Tarawih sebagaimana disampaikan Bapak H. Imran Na'tot. Peran masjid sangat berpengaruh dalam kekrabatan masyarakat Melayu Sambas di Kecamatan Semparuk. Sehingga masyarakat Melayu Sambas memiliki hubungan emosional yang kuat sesama Melayu salah satunya melalui peran masjid.

\section{Masjid, Komunitas Melayu Sambas, dan Character Building}

Masjid yang ada di Semparuk Kabupaten Sambas, bagi Melayu Sambas tidak hanya terfungsikan sebatas tempat ibadah seperti salat, atau tempat-tempat seremonial peringatan hari besar Islam, melainkan bagi komunitas dirawat fungsifungsi sosial dan kemasyarakatannya. Hal ini jelas berdampak positif bagi tujuan-tujuan pembangunan karakter. Dari hasil pengamatan dan wawancara yang dilakukan, menunjukan bagaimana masjid yang ada di desa-desa Kecamatan Semparuk, masih mampu bertahan di tengah gempuran hedonism dan pragmatism yang menggejala di kota-kota, sebutlah seperti Pontianak. Pendidikan karakter tidak boleh semata-mata mengandalkan sekolah tetapi sudah sepatutnya pendidikan karakter berbasis masyarakat dalam hal ini masjid menjadi sarana dalam membangun karakter (Kurniawan, 2014).

Masjid bukan hanya semata tempat ibadah melainkan juga sebagai tempat bermacam-macam 
kegiatan dilakukan di masjid. Hal itu disampaikan oleh H. Imran Na'tot menyebutkan bahwa kegiatan yang dilakukan di masjid berpengaruh terhadap jumlah jemaah saat ibadah salat di masjid. Selain itu, beliau menyebutkan semakin banyak kagiatan yang dilakukan semakin bertambah jemaah masjid. Hal itu, beliau contohkan di masjid Istiqbal di desa Sepadu pada saat kegiatan di masjid rutin dilakukan setidaknya jemaah bertambah berkisar 20 orang. Kegiatan-kegiatan yang dilakukan mempengaruhi bertambahnya jemaah salat wajib dan bahkan banyaknya jumlah jemaah bertahan setiap harinya. Beliau menambahkan apabila dalam sebulan kegiatan tidak dilakukan maka secara berangsurangsur jemaah akan berkurang.

Informasi yang disampaikan $\mathrm{H}$. Imran Na'tot ini sejalan dengan pandangan Aisyah N. Handryanti (2010), bahwa masjid selain memenuhi keperluan ibadah Islam, fungsi dan perannya ditentukan oleh lingkungan, tempat dan jemaah di mana masjid didirikan. Secara prinsip, masjid adalah tempat membina umat, yang meliputi penyambung ukhuwah, wadah membicarakan masalah umat, serta pembinaan dan pengembangan masyarakat.

Juanda menyebutkan bahwasanya masjid mempunyai peran yang besar dalam membangun karakter pemuda dari komunitas Melayu Sambas yang ada di Kecamatan Semparuk. Tidak, hanya persoalan ibadah saja masjid juga merupakan tempat berkumpul dan berdiskusinya para pemuda dan membicarakan semua informasi tentang agama. Juanda menambahkan saat ini banyak pemuda dari komunitas Melayu Sambas tertarik dan banyak mendapatkan inspirasi tentang kebaikan setelah berkumpul di masjid, sebelum dan setelah salat.

Contoh lainnya adalah bagaimana banyak unitunit usaha yang mulai dibangun dari perkumpulan di masjid. Saat ini banyak pemuda Semparuk yang sudah membuka usaha sendiri dengan memanfaatkan jaringan masjid. Sehingga yang tadinya masjid hanya sebatas untuk sarana ibadah berubah fungsi sebagai membangun ide perekonomian masyarakat. Perubahan fungsi yang dilakukan pemuda dari komunitas Melayu Sambas di Kecamatan Semparuk ini merupakan penerapan fungsi masjid dalam ruang publik yaitu ruang komunitas Melayu Sambas. Kaitan dengan ini, Ismail Ruslan (2012) mengasumsikan bahwa pemberdayaan ekonomi masyarakat berbasis masjid adalah sebuah konsep reaktualisasi dan tafsir tekstual masyarakat.

Dengan kata lain, fungsi masjid melalui ruang yang dibangunnya berdampak positif bagi komunitas Melayu Sambas, terutama dalam membuka peluangpeluang kerja baru yang diikuti oleh etos kerja seperti bagi pemuda suku Melayu Sambas di Semparuk. Tentu saja hal ini, pernah dipraktikkan dalam kehidupan masa-masa awal di bawah teladan Rasulullah Saw. Sejarah mencatat bagaimana salah satu fungsi masjid pada masa Rasulullah yaitu sebagai pusat pemberdayaan ekonomi umat melalui Baitul Mal (ZISWAF) (Dalmeri, 2014).

Berdasarkan sumber data dokumentasi penyuluh agama di Kecamatan Semparuk setidaknya ada beberapa kegiatan yang rutin dilakukan pada masjid yang ada di Kecamatan Semparuk, berikut tabel kegiatan masjid di Semparuk:

Tabel 1.

Kegiatan pada masjid-masjid

Se-kecamatan Semparuk kabupaten Sambas

\begin{tabular}{|c|l|l|}
\hline No & \multicolumn{1}{|c|}{ Jenis Kegiatan } & \multicolumn{1}{|c|}{ Tempat Kegiatan } \\
\hline 1 & Pengajian Keliling & Masjid Al-Ikhlas \\
\hline 2 & Ceramah Isra' Mi'raj & Masjid Al-Falah \\
\hline 3 & Ceramah Isra' Mi'raj & $\begin{array}{l}\text { Masjid Ummatul } \\
\text { Islamiyah }\end{array}$ \\
\hline 4 & BKMT Kecamatan Semparuk & Masjid Al-Hikmah \\
\hline 5 & TPA \& IRMAS & Masjid Istiqbal \\
\hline 6 & PHBI & Masjid Istiqbal \\
\hline 7 & Pengajian Keliling & Masjid Al-Kautsar \\
\hline 8 & Pengajian Rutin & Masjid Al-Falah \\
\hline 9 & Lomba TPQ & Masjid Al-Ikhlas \\
\hline 10 & Pengajian Rutin Ibu Lansia & Masjid Istiqbal \\
\hline 11 & $\begin{array}{l}\text { Safari Ramadan, Buka } \\
\text { Bersama, }\end{array}$ & Seluruh Masjid \\
\hline 12 & Kegiatan Ramadan & Seluruh Masjid \\
\hline 13 & Pengajian & Masjid Baitul Falah \\
\hline 14 & Tausiah & Masjid As-Sodoqin \\
\hline 15 & Pengajian Ibu Lansia & Surau Al-Anshor \\
\hline 16 & Acara BKMT & Masjid Al-Quba \\
\hline 17 & Paruk Khatamul Qur'an & Masjid Al-Quba \\
\hline 18 & Arisan PKK & Masjid Istiqbal \\
\hline 19 & Menyambut jamaah haji & Masjid Ar-Raudhah \\
\hline 20 & $\begin{array}{l}\text { Pengajian Ibu Lansia dan } \\
\text { dewasa }\end{array}$ & Masjid An-Nur \\
\hline 21 & Pemuda Hijrah & Masjid Ar-Raudhah \\
\hline 22 & $\begin{array}{l}\text { Acara MTQ Kecamatan } \\
\text { Semparuk }\end{array}$ & $\begin{array}{l}\text { Masjid Kecamatan } \\
\text { Semprauk }\end{array}$ \\
\hline
\end{tabular}

(Sumber: Data Penyuluh Agama Kabupaten Sambas, 11 November 2018)

Intizar, Vol. 25, No. 1, Juni 2019 
Data di atas menunjukkan setidaknya fungsi masjid tidak hanya sebatas sarana ibadah saja. Berdasarkan sumber informasi Bapak Pian menyebutkan salah satu masjid Al-Ikhsan di desa Seburing tidak hanya dijadikan tempat ibadah. Masjid juga dijadikan sarana untuk menjalankan tradisi yang dilaksanakan oleh masyarakat Melayu Sambas. Salah satu tradisi yang dilaksanakan dalam masjid, yaitu tradisi makan amping.

Masyarakat berkumpul bersama di masjid dan bersilaturahmi di masjid. Masjid sebagai sarana untuk melaksanakan tradisi yang berlangsung pada masyarakat Melayu Sambas sesuai dengan teori Sidi Gazalba (1974) yang menyebutkan masjid sebagai pusat ibadat dan kebudayaan Islam. Sistem nilai ini memang dekat dengan identitas kemelayuan, dalam pengertian menjalankan tradisi sebuah kebutuhan bagi komunitas/ masyarakat yang harus dijalankan sebagai Melayu dan Muslim sekaligus.

Supardi dan Teuku Amiruddin (2001) menyebutkan jamaah masjid baru akan mencintai masjid kalau masjid memperhatikan kebutuhan jamaah baik kebutuhan moral ataupun material. Komunitas Melayu Sambas khususnya pada komunitas Melayu di Kecamatan Semparuk menjadikan masjid tempat bermusyawarah baik itu dalam kegiatan sosial, misalnya: rapat kerja bakti, mengumumkan informasi desa, atau kegiatan masyarakat lainnya. Tidak hanya itu, masjid juga dijadikan untuk menyambut tamu-tamu penting misalnya, bupati, camat, anggota dewan bahkan menyambut mahasiswa yang biasanya melakukan KKN di desa tersebut.

Penerapan fungsi masjid yang dilakukan oleh masyarakat Melayu Sambas di Semparuk saat ini sesuai dengan fungsi masjid di zaman Rasulullah Saw. Syamsul Kurniawan (2014) menyebutkan fungsi masjid zaman Rasulullah Saw, yaitu: tempat ibadah umat Islam, tempat menuntut ilmu umat Islam, tempat memberi fatwa, tempat mengadili perkara, tempat menyambut tamu, tempat melangsungkan pernikahan, tempat layanan sosial, tempat latihan perang, dan tempat layanan medis dan kesehatan.

Sedangkan fungsi masjid pada zaman kolonial menjajah di Nusantara masjid digunakan sebagai sarana menyusun strategi dan dari masjid itulah basis kekuatan umat Islam hadir (Hidayat, 2014). Berdasarkan pengamatan, masjid juga dijadikan sebagai tempat kampanye politik, seperti kasus Masjid Istiqbal. Selain itu, beberapa sumber informasi juga menyatakan hal yang sama terkait masjid dijadikan tempat mengampanyekan pesanpesan politik khususnya pada beberapa masjid yang ada di kecamatan Semparuk. Masyarakat menerima calon kepala daerah atau calon legislatif untuk bersilaturahmi di masjid. Calon kepala daerah atau calon legislatif biasanya membawa ustaz untuk memberikan tausiah kepada masyarakat.

Jika dilihat dari sejarahnya Rasulullah Saw tidak melarang aktifitas politik di masjid. Sidi Gazalba (1974) membeberkan bagaimana zaman Nabi kehidupan politik berpusat pada masjid, sama dengan kepentingan berpolitik masyarakat modern yang seringkali memanfaatkan masjid dalam konteks ini. Kecuali, Masjid Dhirar yang di dalam sejarah, dibangun oleh kelompok yang memusuhi Islam, untuk kepentingan propaganda politik dan memecah belah umat Islam, dalam konteks ini Islam mengecamnya (Kurniawan, 2014).

\section{Revitalisasi Masjid dalam Membangun Karakter Masyarakat pada Komunitas Melayu Sambas}

Kegiatan yang bersifat sosial dan kemasyarakatan berpengaruh pada kehidupan komunitas Melayu Sambas di Kecamatan Semparuk. Masjid yang sebagai sarana ibadah untuk mendekatkan diri kepada Allah Swt. akhir-akhir ini juga tercitrakan sebagai sarana dalam membangun karakter, terutama bagi komunitas suku Melayu Sambas; baik dari kalangan anak-anak, remaja, bahkan dewasa. Sangat relevan dengan pendapat Syamsul Kurniawan (2014), di mana fungsi tempat ibadah semestinya tidak hanya dibatasi pada tempat melaksanakan ibadah saja, tetapi juga tempat menggelar diskusi, menggelar ceramah-ceramah, atau dialog-dialog keagamaan, tempat pembinaan remaja dan anak usia dini, tempat musyawarah, dan lain-lain. Dengan demikian, tempat-tempat ibadah dapat menjadi pusat penyemaian nilai-nilai karakter masing-masing individu di masyarakat.

Salah satu fungsi masjid sebagai sarana dalam membangun karakter dapat dilihat di Masjid Dusun 
Gresik yang mana masjid menjadi tempat pembinaan remaja. Kegiatan masjid yang dilaksanakan salah satunya zikir Nazzam. Zikir Nazzam dilakukan pada setiap malam Minggu dengan dipandu oleh para orang tua yang ada di Masjid Baiturrohim. Kegiatan tersebut diikuti oleh anak-anak dan remaja. Anakanak dan remaja dilatih para orang tua untuk berzikir Nazzam sebagai penerus generasi. Biasanya anakanak dan remaja dilatih untuk bergendang dalam zikir Nazzam. Masjid berfungsi sebagai sentral kegiatan bagi masyarakat Melayu Sambas di masjid Baiturrohim sebagaimana disampaikan Bapak Amat dan Aunur. Hal ini relevan dalam pandangan Muhsinah Ibrahim (2013) menyebutkan masjid tidak hanya berfungsi sebagai sarana ibadah tetapi merupakan pusat kegiatan sosial kemasyrakatan (mu'asalah) dan lebih jauh lagi masjid merupakan sentral kegiatan umat Islam.

Selain itu, Masjid Al-Ihsan yang terdapat di dusun Mulia desa Seburing masyarakat Melayu fungsikan sebagai tempat pelaksanaan tradisi yang turun menurun dilakukan. Salah satu tradisi yang dilaksanakan masyarakat di Masjid Al-Ihsan pada setiap bulan suci Ramadan yang bertepatan dengan 7 likur dalam bulan Ramadan masyarakat berbuka puasa bersama dengan membawa kue pasong di masjid. Tradisi berbuka dengan kue pasong yang dimakan secara bersama-sama dilakukan oleh kaum laki-laki dan diikuti oleh anak-anak dan remaja yang ada di dusun Mulia desa Seburing sebagaimana disampaikan Bapak Lani Sumran dan Labai.

Selain sebagai sarana dalam menjalankan tradisi, masjid bagi komunitas Melayu Sambas juga sebagai sarana pendidikan, khususnya komunitas Melayu yang ada di Kecamatan Semparuk. Fungsi masjid juga dapat sebagai mempertahankan nilainilai kebudayaan masyarakat Islam serta dapat membangun masyarakat dan membebaskan masyarakat dari keterbelakangan (Ikhwan, 2013). Banyak Taman Pengajian Qur'an (TPQ) yang rutin dilaksanakan di masjid yang ada di kecamatan Semparuk. Salah satu masjid yang memberikan pendidikan terhadap anak-anak adalah Masjid Istiqbal. Masjid Istiqbal membangun karakter anak melalui TPQ yang ada di masjid. Untuk peserta TPQ terdiri dari anak-anak yang berusia 5-8 tahun sebagaimana disampaikan Bapak Muis dan Labai.
Berdasarkan pengamatan yang dilakukan, dampak dari TPQ yang diadakan di Masjid Istiqbal membuat anak-anak dapat menghafal beberapa surah pendek dan doa-doa sehari-hari. Thomas Lickona (2013) menyebutkan kebiasaan merupakan faktor pembentuk perilaku moral. Sedangkan untuk pendidikan karakter bagi para remaja dengan dibentuknya ikatan remaja masjid yang ada di kecamatan Semparuk. Sehingga setiap desa mempunyai remaja masjid. Kegiatan yang dilakukan oleh para remaja tidak hanya sebatas ikut memeriahkan acara besar Islam melainkan juga berperan dalam memakmurkan masjid. Berdasarkan data yang didapatkan saat ini jamaah salat di masjid di kecamatan Semparuk tidak hanya didominasi oleh orang tua saja melainkan sudah diramaikan oleh remaja dan pemuda yang ada kecamatan Semparuk sebagaimana disampaikan Bapak Amat.

Masjid Ar-Raudhah salah satu masjid yang mengalami perkembangan jamaah dari kalangan anak muda. Dalam beberapa tahun terakhir jamaah dari kalangan muda sudah banyak yang melaksanakan salat wajib di masjid. Hal itu diungkapkan Juanda bahwa dahulu anak muda yang dapat dikatakan nakal dan dahulu sering menghabiskan waktu di pasar sekarang sudah mulai melaksanakan salat wajib di masjid. Bahkan, menurut Juanda jamaah salat wajib telah di dominasi oleh kaum muda. Tidak hanya dalam melaksanakan salat wajib beberapa kaum muda juga mengadakan pengajian di masjid bahkan bergabung dengan beberapa remaja masjid yang ada di kecamatan Semparuk. Redi menyebutkan saat ini kegiatan masjid yang berkaitan dengan remaja sangat berpengaruh terhadap pergaulan para remaja. Aktifnya kegiatan masjid membuat remaja dan pemuda yang sebelumnya sering keluar malam sekarang sudah beralih berkumpul di masjid. Bahkan, menurut Redi saat ini jika dilihat dari fenomenanya tingkat kenakalan remaja sudah berkurang dibanding beberapa tahun sebelumnya. Erie Sudewo (2011) karakter adalah sejumlah sifat baik yang menjadi perilaku sehari-hari.

Salah satu faktor menurunnya kenakalan remaja, adalah karena ketertarikan remaja atau pemuda untuk beraktifitas dan atau melibatkan diri dalam kegiatan-kegiatan masjid. Hal yang sama juga

Intizar, Vol. 25, No. 1, Juni 2019 
disampaikan oleh Eko menyebutkan jamaah masjid Ummatul Islam saat ini tidak hanya dipenuhi oleh orang tua melainkan banyak dari remaja dan anak muda yang sudah mulai rutin datang ke masjid.

Peran pemuda dalam masjid berdampak besar dalam pergaulan remaja dan pemuda yang ada di kecamatan Semparuk. Masalah pergaulan bebas yang ada saat ini pada dasarnya dapat ditangani melalui kegiatan-kegiatan di masjid sebagaimana diungkapkan Bapak Bahni dan Labai. Setidaknya peran masjid pada komunitas melayu Sambas dalam membangun karakter terdapat nilai religius didalam fungsinya. Nilai religius merupakan suatu sikap keberagamaan (Sudewo, 2011).

Komunitas melayu Sambas hal ini peran masjid dalam membangun karakter terwujud melalui akhlak. Seperti, yang telah dijelaskan bahwa pada saat ini kenakalan remaja sudah menurun dengan aktifnya kegiatan yang dilakukan di masjid komunitas melayu Sambas. Sikap keberagamaan yang diaplikasikan dalam salat jamaah di masjid tidak hanya dilakukan oleh kalangan tua melainkan didominasi oleh kalangan muda. Hal itu menunjukkan bahwa masjid merupakan sarana pendidikan karakter sehingga membangun nilai religius pada pemuda melayu Sambas. Nilai religius yang dibangun oleh komunitas melayu Sambas merupakan wujud dari cinta kepada Allah. Hal itu sejalan Sabar Budi Raharjo (Sudewo, 2011) dengan pandangan bahwa pendidikan karakter dilaksanakan untuk mencapai perubahan pada diri sendiri dan masyarakat.

Nilai bersahabat juga tampak dalam kegiatan yang dilakukan oleh masyarakat melayu Sambas di masjid. Kebersamaan komunitas melayu Sambas dapat dilihat dari pelaksanaan tradisi, seperti makan amping dan kue pasong di bulan Ramadan yang dilakukan di masjid. Masyarakat Melayu Sambas berkumpul bersama di masjid sehingga masjid yang merupakan tempat ibadah masyarakat jadikan sebagai tempat berkumpul. Tidak hanya itu, masjid juga sebagai tempat berkumpulnya seluruh remaja dan pemuda yang ada di kecamatan Semparuk di bawah naungan Ikatan Remaja Masjid (IRMAS). Sehingga masjid komunitas Melayu Sambas di Kecamatan Semparuk membangun nilai bersahabat yang mana persatuan saat ini sudah mulai berkurang.

\section{Keterlibatan Remaja Masjid dan Pemuda Hijrah, serta Konsekuensinya bagi Masjid dalam Komunitas Melayu Sambas}

Perubahan sosial yang berlangsung cepat, di mana masyarakat menerima beragam informasi tentang segala hal termasuk agama dengan sangat mudah karena kecanggihan smartphone. Terlepas dari dampak negatif yang ditimbulkan, sedikit banyak media baru ini juga memberikan konsekuensi positif bagi pemuda, untuk melakukan hijrah, dalam pengertian sebuah tren di mana seorang pemuda kembali pada ajaran-ajaran Islam yang sebelumnya ia tinggalkan.

Hijrah yang dilakukan oleh kalangan muda yang ada di kecamatan Semparuk menumbuhkan semangat baru dalam memakmurkan masjid. Hijrah yang ada di kecamatan Semparuk seperti yang peneliti amati bukanlah hijrah Salafi. Para pemuda menyebutnya dirinya berhijrah dikarenakan perubahan yang dialami. Dahulu, jarang ke masjid sekarang rutin melaksanakan ibadah ke masjid. Hal itu disampaikan oleh Juanda yang menyebutkan hijrah yang dilakukan oleh pemuda bukanlah Salafi melainkan mengajak pemuda untuk berubah lebih baik dan memakmurkan masjid. Selain itu, pemuda yang saat ini rutin datang ke masjid dulunya merupakan pemuda yang sering berkumpul di pasar.

Aktifnya remaja masjid yang umumnya disebut pemuda hijrah, dalam beberapa kegiatan yang ada di kecamatan Semparuk menjadi aktor utama dalam membangun karakter terhadap komunitas Melayu Sambas di Kecamatan Semparuk, terutama sesama remaja atau pemuda. Saat ini setiap desa di kecamatan Semparuk mempunyai remaja masjid dan mewakili desa-desa masing-masing. Kegiatan yang dilakukan remaja tidak hanya sekedar mengadakan kegiatan keagamaan melainkan juga mengadakan kegiatan diluar masjid dan bergabung antara remaja masjid satu dengan yang lain, misalnya: mengadakan acara silaturahmi, mengadakan acara outbond bersama, pawai bersama pada acara hari besar Islam dan melaksanakan kegiatan rutin membersihkan masjid sebagaimana diungkapkan Bapak Amat.

Salah satu pengaruh yang paling besar dari aktifnya remaja masjid seperti, di desa Sepadu sudah belasan tahun tidak lagi mengadakan takbir keliling yang ada di desa Sepadu. Saat ini dalam 2 (dua) 
tahun terakhir sudah kembali mengadakan acara takbir keliling desa yang diikuti oleh anak-anak dari SD hingga SMA. Remaja masjid merupakan buah hasil dari pendidikan karakter yang ada di masjid. Jika fungsi masjid sebagai sarana membangun karakter bagi masyarakat lebih dioptimalkan bukan tidak mungkin masjid menjadi wadah terpenting dalam membangun karakter bagi komunitas Melayu Sambas sebagaimana diungkapkan Bapak H. Imran Na'tot.

Kecuali remaja masjid, mahasiswa dan alumni dari berbagai perguruan tinggi, khususnya perguruan tinggi kegamaan Islam yang kembali ke Sambas, ikut menjadi aktor dalam mengampanyekan pentingnya hijrah sebagai bagian dalam memperbaiki dan membangun karakter di komunitas Melayu Sambas. Saat ini banyak pemuda Semparuk yang melanjutkan studi baik sekolah maupun kuliah. Bagi pemuda yang kuliah rata-rata melanjutkan di perguruan tinggi swasta dan negeri yang ada di Sambas dan Pontianak. Pemahaman agama yang didapatkan oleh mahasiswa asal kecamatan Semparuk didapatkan ketika kuliah di perguruan tinggi Islam dan atau organisasi serta lembaga dakwah kampus bagi mahasiswa yang berasal dari perguruan tinggi umum. Ketika mendapatkan ilmu agama tersebut mahasiswa mengaplikasikannya kembali di kampung halaman masing-masing baik memakmurkan masjid maupun mengadakan pengajian-pengajian sebagaimana diungkapkan Bapak Azhari.

Pada konteks ini, komunitas-komunitas kecil yang dibangun oleh mahasiswa berdampak besar dalam perubahan masjid. Masjid yang dulu didominasi oleh kaum tua saat ini berubah dipengaruhi oleh kaum muda sehingga pemuda menjadi agen perubahan dalam fungsi masjid. Kalangan tua berharap adanya perubahan yang dilakukan oleh kalangan muda dalam mereformasi masjid pada saat ini melalui ilmu yang didapatkan lewat pendidikan sebagaimana diungkapkan Bapak Rumli. Dari yang dipaparkan di atas nampak ada peran penting pemuda hijrah dalam merevitalisasifungsi-fungsi masjid, sehingga menjadi tempat kondusif dalam membangun karakter. Kegiatan-kegiatan yang dimotori mereka secara tidak langsung bermanfaat dalam membangun karakter orang-orang dalam komunitas Melayu Sambas diakui sangat mengembalikan muruah masjid di zaman ini sebagaimana diungkapkan Bapak H. Lani Sumran.

Masjid adalah tempat yang tepat bagi remaja atau pemuda (Basit, 2009). Tidak hanya sebagai tempat yang kondusif bagi pembangunan karakter, remaja dan pemuda dapat ikut terlibat dalam kegiatan-kegiatan masjid dalam hal sosial, budaya dan kemasyarakatan yang membangun karakter, di mana masjid sebagai wadahnya. Berdasarkan penelitian yang peneliti lakukan, remaja masjid dan komunitas pemuda hijrah, kenyataannya dapat bersama-sama dan saling bantu membantu, memakmurkan masjid di mana mereka terlibat sebagai aktor. Dengan keterlibatan mereka dalam kegiatan-kegiatan masjid, masjid bukan hanya menjadi tempat yang berfungsi sebagai sarana ibadah, tetapi juga sebagai sarana dalammembangun karakter. Relevan terhadap pandangan Syamsul Kurniawan (2014) menjelaskan masjid seharusnya sebagai tempat pembinaan dan kaderisasi umat, serta menjadi sentra utama aktivitas keutamaan, yaitu pendidikan, politik, ekonomi, sosial, dan budaya.

Berkat keterlibatan aktif remaja dan pemuda yang menamakan diri mereka remaja masjid dan pemuda hijrah, kegiatan-kegiatan masjid bisa semarak. Tentu tidak hanya diperuntukkan bagi remaja dan pemuda. Banyak kegiatan-kegiatan masjid yang diperuntukkan untuk orang-orang tua (lanjut usia) dalam komunitas Melayu Sambas. Misalnya: pengajian ibu PKK, pengajian ibu Lansia, acara BKMT, zikir Nazzam, mengaji rutin setiap malam Jumat, dan lain-lain sebagaimana diungkapkan Bapak Amat.

Kegiatan yang diperuntukkanpada kelompok orang-orang tua (lanjut usia), baik bagi bapak-bapak atau ibu-ibu setidaknya dapat memberikan momentum untuk pendidikan agama Islam. Sehingga dari pengajian yang mereka ikuti mereka mendapatkan bekal dalam memberikan pendidikan agama dalam keluarga khususnya kepada anak-anak atau cucu-cucunya sebagaimana diungkapkan Bapak Bahni, Labai, dan Muis. 


\section{Kesimpulan}

Hasil penelitian ini menunjukkan sebuah tren positif tentang posisi masjid yang punya peran dalam membangun karakter. Setidaknya ini terjadi karena masjid diperlakukan tidak saja sebagai tempat ibadah atau seremonial peringatan hari besar Islam saja, melainkan juga tempat berlangsungnya kegiatankegiatan sosial budaya kemasyarakatan. Aktor utamanya adalah remaja masjid dan pemuda hijrah. Tentu ini bukanlah sebuah hal tanpa model. Berdasarkan informasi sejarah kita akan menemukan bagaimana fungsi masjid pada zaman Rasulullah Saw juga berorientasi tidak sebatas tempat ibadah melainkan juga untuk melakukan aktifitas pendidikan, politik, ekonomi, sosial, dan budaya.

Kegiatan-kegiatan yang ada di masjid-masjid komunitas Melayu Sambas yaitu diKecamatan Semparuk seperti kegiatan TPQ, BKMT, PHBI, Pengajian Lansia dan Dewasa, melestarikan tradisi, diskusi-diskusi para pemuda, dan silaturahmi masyarakat dapat menumbuhkan kepedulian masyarakat terhadap masjid sehingga akan berdampak terhadap pemakmuran masjid. Kegiatankegiatan tersebut bukan hanya bentuk penghambaan terhadap Allah SWT yang hanya berkaitan dengan iman dan takwa melainkan juga bentuk dari sikap sosial antar masyarakat dalam komunitas Melayu Sambas. Setidaknya dengan aktifitas ini, komunitas Melayu Sambas terkondisikan dalam situasi dan kondisi yang mendukung bagi terbangunnya karakter mereka, ke arah yang positif. Setidaknya masjid pada komunitas melayu Sambas di Kecamatan Semparuk berpengaruh dalam membangun karakter sehingga masjid membangun nilai religius sehingga jumlah jamaah yang melaksanakan ibadah salat bertambah bahkan didominasi kalangan muda. Selain itu, masjid sebagai tempat menggelar diskusi, menggelar ceramah-ceramah, atau dialog-dialog keagamaan, tempat pembinaan remaja dan anak usia dini, tempat musyawarah

Nilai bersahabat pada komunitas melayu Sambas juga tampak dalam pelaksanaan tradisi yang dilakukan oleh komunitas melayu Sambas di masjid. $\mathrm{Ha}$ itu menumbuhkan rasa persatuan dan persaudaraan antar masyarakat melayu Sambas yang berkumpul bersama di masjid dan bersilaturahmi di masjid. Masjid sebagai sarana untuk melaksanakan Intizar, Vol. 25, No. 1, Juni 2019 tradisi yang berlangsung pada masyarakat Melayu Sambas

\section{Daftar Pustaka}

Basit, A. (2009). Strategi Pengembangan Masjid Bagi Generasi Muda. Jurnal Dakwah Dan Komunikasi, 3(2).

Dalmeri. (2014). Revitalisasi Fungsi Masjid Sebagai Pusat Ekonomi dan Dakwah Multikultural. Walisongo, 22(2).

Gazalba, S. (1974). Mesjid Pusat Ibadah dan Kebudayaan. Jakarta: Pustaka Antara.

Handryant, A. N. (2010). Masjid Pusat Pengembangan Masyarakat Integrasi Konsep habluminallah, habluminannas, dan habluminal'alam. Malang: UIN Maliki Press.

Hermansyah. (2015). Islam dan Melayu di Borneo. Pontianak: IAIN Pontianak Press.

Hidayat, A. (2014). Masjid Dalam Menyikapi Peradaban Baru. Ibda' Jurnal Kebudayaan Islam, 12(1).

Ibrahim, M. (2013). Pendayagunaan Mesjid dan Menasah Sebagai Lembaga Pembinaan Dakwah Islamiyah. Al-Bayan, 19(2).

Ikhwan, A. (2013). Optimalisasi Peranan Masjid Dalam Pendidikan Anak: Perspektif Makro dan Mikro. Edukasi, 1(1).

Jurdi, S. (2014). Sosiologi Islam dan Masyarakat Modern: Teori, Fakta, dan Aksi Sosial. Jakarta: Kencana.

Kemenag, S. (2018). Profil Masjid Kecamatan Semparuk.

Kurniawan, S. (2014). Masjid Dalam Lintasan Sejarah Umat Islam. Khatulistiwa, 4(2).

Lamazi. (2015). Kosmologi Melayu: Studi Pada Arsitektur Masjid Kesultanan Sambas. Khatulistiwa, 5(1).

Lickona, T. (2013). Pendidikan Karakter: Panduan Lengkap Mendidik Siswa Menjadi Pintar dan Baik. Bandung: Nusa Media.

Mahrus, E., \& Moh Haitami Salim. (2008). Pengantar Studi Islam. Pontianak: STAIN Pontianak Press.

Ruslan, I. (2012). Pemberdayaan Ekonomi Masyarakat Berbasis Masjid di Pontianak. Khatulistiwa, 2(1).

Sambas, B. K. (2017). Pengolahan dan Diseminasi 
Statistik, Kecamatan Semparuk dalam angka 2017. Sambas: BPS Kabupaten Sambas.

Sudewo, E. (2011). Best Practice Character Building. Jakarta: Republika.

Supardi, \& Teuku Amiruddin. (2001). Konsep Manajemen Masjid: Optimalisasi Peran
Masjid. Yogyakarta: UII Press.

Wikipedia. (2019). Semparuk, Sambas.

Zein, A. B. (1999). Masjid-Masjid bersejarah di Indonesia. Jakarta: Gema Insani Press. 